\title{
Learning strategies with television series: simple attitudes to improve oral skills
}

\author{
Estratégias de aprendizagem com séries de televisão: atitudes simples para melhorar as habilidades \\ orais \\ Estrategias de aprendizaje con serie de televisión: actitudes simples para mejorar la habilidad oral
}

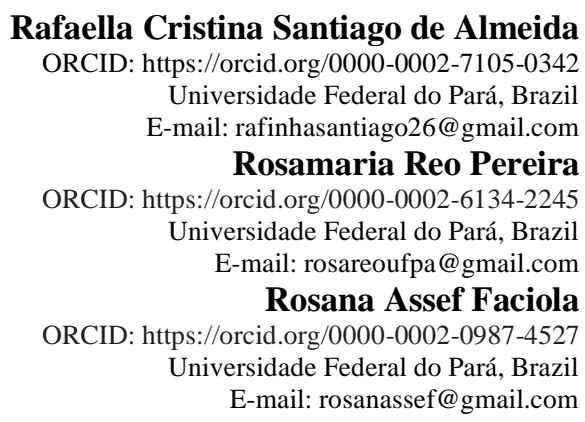

\begin{abstract}
The exposure to authentic materials as TV series provides students with motivating, useful, and contextualized vocabulary, as well as the opportunity to observe language being spoken by natives during real-life circumstances. Though, solely exposure to the language may not be sufficient to improve students' language abilities. Thereat, this research aimed at investigating how television series can assist students' oral abilities; by examining what mechanisms (learning strategies) students most use to properly comprehend the dialogues presented in such programs, as well as to observe students' perception of their listening and speaking abilities. The methodology adopted in this study was exploratory, with the approach to the research occurring quantitatively and qualitatively, by field research, through a questionnaire administration, and a literature review examination. This study demonstrated that the importance of exposure to the target language resides thoroughly on students' attitudes towards the material, rather than to the pure amount of exposure on itself, the strategies learners employ to manipulate the information, and to monitor their understanding are primary determinants for language acquisition. In conclusion, the study demonstrated to teachers the necessity of practicing such strategies and to students the relevance of developing control of their language learning process, therefore becoming autonomous learners.
\end{abstract}

Keywords: Language exposure; Oral skills; Authentic materials.

\section{Resumo}

A exposição a materiais autênticos como séries de TV fornece aos alunos vocabulário motivador, útil e contextualizado, bem como a oportunidade de observar a linguagem sendo falada pelos nativos em circunstâncias da vida real. No entanto, a exposição exclusiva ao idioma pode não ser suficiente para melhorar as habilidades linguísticas dos alunos. Assim, essa pesquisa teve como objetivo investigar como as séries de televisão podem ajudar as habilidades orais dos alunos; examinando quais mecanismos (estratégias de aprendizagem) os alunos mais usam para compreender adequadamente os diálogos apresentados em tais programas, bem como para observar a percepção dos alunos sobre suas habilidades de escuta e fala. A metodologia adotada neste estudo foi exploratória, com abordagem de pesquisa quantitativa e qualitativa, por pesquisa de campo, por meio da aplicação de questionário e exame de revisão de literatura. Este estudo demonstrou que a importância da exposição à língua-alvo reside muito nas atitudes dos alunos em relação ao material, e não à quantidade pura de exposição em si mesma, as estratégias que os alunos empregam para manipular as informações e monitorar sua compreensão são os principais determinantes para aquisição de linguagem. Concluindo, o estudo demonstrou aos professores a necessidade de praticar tais estratégias e aos alunos a relevância de desenvolver o controle de seu processo de aprendizado de idiomas, tornando-se aprendizes autônomos.

Palavras-chave: Exposição ao idioma; Habilidade orais; Materiais autênticos.

\section{Resumen}

La exposición a materiales auténticos como series de televisión les brinda a los estudiantes un vocabulario motivador, útil y contextualizado, así como la oportunidad de observar el lenguaje hablado por los nativos durante circunstancias de la vida real. Sin embargo, la exposición exclusiva al idioma puede no ser suficiente para mejorar las habilidades lingüísticas de los estudiantes. Por lo tanto, esta investigación tuvo como objetivo investigar cómo 
las series de televisión pueden ayudar a las habilidades orales de los estudiantes; examinando qué mecanismos (estrategias de aprendizaje) utilizan más los estudiantes para comprender adecuadamente los diálogos presentados en dichos programas, así como para observar la percepción de los estudiantes de sus habilidades para escuchar y hablar. La metodología adoptada en este estudio fue exploratoria, y el enfoque de la investigación se realizó cuantitativa y cualitativamente, mediante investigación de campo, mediante la administración de un cuestionario y un examen de revisión de la literatura. Este estudio demostró que la importancia de la exposición al idioma de destino reside completamente en las actitudes de los estudiantes hacia el material, más que en la cantidad pura de exposición en sí mismo, las estrategias que los estudiantes emplean para manipular la información y monitorear su comprensión son los principales determinantes para la adquisición de idiomas. En conclusión, el estudio demostró a los docentes la necesidad de practicar tales estrategias y a los estudiantes la relevancia de desarrollar el control de su proceso de aprendizaje de idiomas, convirtiéndose así en aprendices autónomos.

Palabras clave: Exposición al lenguaje; Habilidades orales; Materiales auténticos.

\section{Introduction}

Though listening has been given the role of secondary ability for a long time, recent studies have focused on demonstrating its importance (Rost, 1990; Goh, 1999; Brown, 2001; Nunan, 2001; Vandergrift, 2004; Osada, 2004), concluding that listening, like any other language skill, requires constant practice and personal investment.

The pursue for ways to improve student's learning process had a boost in the late 70s, when Rubin (1975), introduced the concept of 'the good and bad learner', by researching the techniques, or learning strategies that good students used, as a means of improving language learning. Since then, researchers have focused their efforts on identifying, classifying, and observing the impacts of such strategies on the learning process (Rubin, 1975; O’Malley et al., 1985; Oxford, 1990; Vandergrift, 1997).

Nowadays, with advances in technology in cell phones and internet services, students have access to a variety of audio content, such as; music, movies, ted talks, documentaries and television series. Media service providers like Netflix and Youtube have given students the ability to access these content anywhere and anytime of the day. In 2017, "Netflix had approximately six million subscribers to streaming video content in Brazil” (Dias \& Navarro, 2018, p.19). That is, six million people who could to some degree; use this content as a support for language learning.

The idea that television can help with language learning is not new. Nunan (1991) when investigating the techniques used by teachers as a foreign language, to improve their linguistic skills, observed that watching television was a recurring finding, appearing among the ten most used techniques.

As an undergraduate student in the Foreign Languages Graduate Program at the Federal University of Pará, monitor, and teacher at Cursos Livres, a Language course at the same university, I was in contact with several students, with different levels of language and with different interests and habits. I could observe that students, who spend time watching TV series, had an external easiness with both listening and speaking. However, I was also able to observe that many students had great difficulties with these skills and, therefore, often ended their courses with impaired oral abilities.

That said, the study reported here aims to: 1) identify which learning strategies students participating in this research commonly use to effectively understand language in the different TV series they watch, 2) analyze how these strategies can influence their listening comprehension, and speaking performance.

\section{Methodology}

This research is exploratory by nature; it is designed to establish valuable insights on the investigated phenomenon for future studies (Stebbins, 2001). It was carried out on the perspective of the Qualitative-Quantitative Research Methodology (Newman \& Ridenour, 1998) and was developed through field research. 


\subsection{Participants}

The participants involved in the study were forty-four (44) students, 23 males and 21 females with ages varying from 20 to 49 years old. Additionally, 24 participants studied all the seven levels offered by Cursos Livres de Língua Estrangeira (CLLE), 11 participants have made the placement exam and nine participants did not inform the levels they have studied (Table 1). The participants have signed a Consent Term and were addressed by pseudonyms.

Table 1 - Demographic Information for the Main Study Participants.

\begin{tabular}{lc}
\hline Category & Questionnaire respondents $(\mathbf{n}=\mathbf{4 4})$ \\
\hline Gender & \\
Female & 21 \\
Male & 23 \\
Age & \\
$20-24$ & 29 \\
$25-29$ & 6 \\
$30-34$ & 2 \\
Above 34 & 4 \\
Not Informed & 3 \\
Levels studied & \\
at CLLE & \\
All levels & 24 \\
Placement test & 11 \\
Not informed & 9 \\
\hline
\end{tabular}

Source: Prepared by the author of the work.

\subsubsection{Selection procedure of the participants}

The sampling selection of the participants was non-probabilistic; the sample was selected by convenience, since the research was carried out at CLLE, a language course offered by the university. These students were taking the last semester of their course and were chosen because, throughout the course, teachers encourage student's autonomy emphasizing the importance of studying outside the classroom. Furthermore, students who already have familiarity with the language, by autonomous or formal study, can take a placement exam for more advanced levels.

\subsection{Research instrument}

\subsubsection{Using strategies with television shows questionnaire}

The instrument employed in this research was a questionnaire on learning strategies adapted from Oxford's (1990) Strategy Inventory for Language Learning (SILL) and Vandergrift et al. (2006) Metacognitive Awareness Listening Questionnaire (MALQ), in an attempt to observe learning strategies being used outside an institutional context, through watching television series.

The questionnaire was developed in Portuguese using O’Malley et al., (1985) classification of learning strategies, and consists of twenty-six close-ended items, in the form of a five-point Likert scale with answers varying from never (1), rarely (2), sometimes (3), almost always (4) and always (5).

The 26 items were divided into three main categories, namely; 1) background information, divided into two subdivisions; self-awareness and listening outside of the classroom behavior, 2) cognitive strategies, divided into nine subdivisions; listening for details ${ }^{1}$, inferencing, direct physical response, elaboration, repetition, resourcing, imagery,

\footnotetext{
${ }^{1}$ The learning strategy listening for details was added by the researcher. Once, it is an integral strategy for listening comprehension, though is not directly listed in O'Malley et al., (1985) language strategy classification.
} 
contextualization, and translation, and 3) metacognitive strategies divided into four subdivisions; self-monitoring, selfevaluation, self-management, and direct attention.

Furthermore, five open-ended questions were made; 1) How often do you watch television series? 2) Which TV series do you usually watch? 3) How does watching English television series help you with your listening and speaking performance? 4) Have you ever heard about learning strategies? 5) Where have you learned?

\subsection{Procedures}

The collection of data was made on September 2019, in three different moments. They all had duration of approximately $10 \mathrm{~min}$. In this paper, the questionnaires with complete responses for the Likert scale items were validated. All of the validated responses were analyzed. Furthermore, to ensure reliability and internal consistency of the questionnaire the results were validated using Cronbach's alpha formula, both manually in the computer program windows Excel and in the program Statistical Package for Social Science (SPSS version 12.0). To calculate Cronbach's alpha the items (3, 6, 10, 18, and 21) had its scored reversed. The reliability of the questionnaire found is demonstrated in Table 2 :

Table 2 - Reliability Coefficients for the Questionnaire.

\begin{tabular}{lcc}
\hline \multicolumn{2}{c}{ Strategy Category } & Reliability Coefficients \\
\hline Background Information & $(8$ items $)$ & 0,73 \\
Cognitive Strategies & $(10$ items $)$ & 0,62 \\
Metacognitive strategies & $(8$ items $)$ & 0,70 \\
Cognitive and Metacognitive & $(18$ items $)$ & 0,77 \\
Overall questionnaire & $(26$ items $)$ & 0,83 \\
\hline
\end{tabular}

Source: Prepared by the author of the work.

\subsection{Data analysis methodology}

The data obtained quantitatively were analyzed through the program SPSS (Statistical Package for Social Science) version 12.0 and focused on analyzing the frequencies of single items. The data gathered qualitatively were analyzed through the categorization method present in the content analyzes proposed by Bardin (1977/2010).

\section{Results and Discussion}

The research analysis was organized into two main sections: the first section shows the results for the open-ended questions of the questionnaire, specifically data characteristics for the first two questions and analysis for the latter, and the second discussed the results of the Likert scale items of the corresponding questionnaire.

\subsection{Questionnaire open-ended questions results}

\subsubsection{How often do you watch television series?}

To organize the responses, the researcher established intervals of frequency, as demonstrated in Table 3. 
Table 3 - Frequency of Exposure to the TV series.

\begin{tabular}{llc}
\hline Frequency Intervals & Frequency of exposure & $\mathrm{N}^{\mathrm{o}}$ of participants \\
\hline \multirow{4}{*}{ High-frequency } & Daily & 9 \\
& Almost daily & 1 \\
& Four times in a week & 1 \\
& Frequently & 3 \\
& Regularly & 1 \\
& Two or three times in a week & Total:15 \\
& Two times in a week & 1 \\
Medium-frequency & Once or twice a week & 3 \\
& Once a week & 1 \\
& Weekly & 1 \\
& Only weekends & 3 \\
& Sometimes & 3 \\
& & Total: 13 \\
& Twice a month & 3 \\
Low-frequency & With low frequency & 3 \\
& I don't usually watch & 2 \\
& Rarely & 7 \\
& & Total: 15 \\
\hline
\end{tabular}

Source: Prepared by the author of the work.

The findings revealed minimal variations amidst the intervals. As 15 participants had a high-frequency level of watching the television series, 13 participants had a moderate frequency level, and also 15 participants had a low-frequency level, and one student did not inform.

\subsubsection{Which series do you usually watch?}

The results revealed that most participants had a wide-ranging of interests regarding the TV series they watch, as the participants mentioned a variety of TV series in their responses. To best visualize the results, into genres, the programs were organized, as demonstrated in Table 4. 
Table 4 - TV series Genres.

\begin{tabular}{|c|c|c|c|}
\hline Genre & $\mathrm{N}^{\mathrm{o} *}$ & Subgenre & Examples of TV series for each subgenre \\
\hline \multirow[t]{4}{*}{ Comedy } & 19 & Sitcoms & Friends/ TBBT / Brooklyn 99/That's 70 show \\
\hline & & Musical & Glee \\
\hline & & Comedy-drama & Good girls/Master of none \\
\hline & & Comedy & Grace and Frankie \\
\hline \multirow[t]{5}{*}{ Drama } & 22 & Medical & Grey's Anatomy/ The Good Doctor/House \\
\hline & & Legal & How To Get Away With Murder \\
\hline & & Criminal/procedural & La Casa de Papel/Breaking bad/CSI/NCIS \\
\hline & & Historical & Chernobyl/ The Crown \\
\hline & & Teenagers & Gossip Girl \\
\hline \multirow[t]{4}{*}{ Sci-fi/Mystery/horror } & 16 & Science Fiction & Dr. who/Black Mirror \\
\hline & & Mystery & Dexter \\
\hline & & Horror & The Walking dead \\
\hline & & Mystery/horror & Stranger Things/Twin Peaks \\
\hline Fantasy & 4 & & Game of Thrones \\
\hline \multirow[t]{2}{*}{ Action/superhero } & 5 & Action & - \\
\hline & & Superhero & Flash/Arrow/The boys \\
\hline \multirow{2}{*}{ Psychological/dystopian } & 2 & Psychological & You \\
\hline & & Dystopian & The Handmaid's Tale \\
\hline \multirow[t]{3}{*}{ Animation } & 4 & Animation & Rick and Morty \\
\hline & & Cartoons & Pokemon \\
\hline & & Anime & - \\
\hline $\begin{array}{l}*: \text { Number of participant } \\
-: \text { Only informed the gen }\end{array}$ & & & \\
\hline
\end{tabular}

Source: prepared by the author of the work.

The total number of participants $(\mathrm{N}=44)$ was exceeded by the number of participants in all genre categories $\left(\mathrm{N}^{*}=72\right)$ (Table 4). This occurred because the majority of participants were included in more than one category, since 20 participants demonstrated watching three different genres, 10 participants two different genres and 13 participants one single genre, and one participant did not inform.

As observed in Table 4, the most-watched genre was the drama category, though, it was the broader category. Furthermore, the second most-watched genre was the comedy genre; a recurrent finding was the sitcoms or (situational comedies). Additionally, the third most-watched genre observed was the science fiction/mystery/horror. Moreover, the other categories were less recurrent in the responses.

\subsubsection{How does watching television series in English help you with your listening and speaking performance?}

To analyze the content found in this question, the researcher chose to use the categorization process, described in the content analysis proposed by Bardin (1977/2010). For this analysis, the researcher conducted the following steps: a) organization of analysis, b) codification c) categorization d) interpretation of the results (Bardin, 1977/2010).

During the codification procedure, the researcher selected words and phrases from the content of the answers. 10 codes were identified and later classified into five theme categories, namely; Contact with the Language, Authentic Material, Pronunciation, Listening Practice and Comprehension, and Motivation. Afterward, the researcher asked three friends to revise the codes and themes. Their contributions were incorporated into the research.

The first observed theme was: 1) Contact with the language. Several participants stated that watching television series is a useful tool to be in touch with the language, as mentioned by participant Karen and Jonas: 
[5] Karen: "It's the easiest way to get in touch with the language during my day". (Questionnaire) ${ }^{2}$

[40] Jonas: "It helps with exposure to the language, something that is rarely possible in my routine". (Questionnaire) ${ }^{3}$

Such exposure introduced a sentiment of familiarity, observed by most participants, and demonstrated in the commentary of participant David:

[16] David:" Brings me more familiarity with the words". (Questionnaire) ${ }^{4}$

Almost half of the participants pointed out that this familiarity with words and expressions lead to an increase in vocabulary, as observed by Yin (2015), and demonstrated in the comments of participants, Téo, and Luiz:

[32] Téo: "The native speaking helps to increase vocabulary and learn how some expressions should be used in a sentence" (Questionnaire) $)^{5}$

[25] Luiz: "Observing the vocabulary used by the characters in diverse daily contexts". (Questionnaire) ${ }^{6}$

That lead to another theme observed in the results, 2) the authentic material characteristic of the TV series. Morrow (1977, p.13) defined authentic material as "a stretch of real language, produced by a real speaker or writer for a real audience and designed to convey a real message of some sort...". This description ideally illustrated what a television series is, a scripted program, written by natives, with the sole purpose of spreading messages, and entertainment. Thereby, the exposure to native expressions, and informal language features, such as slangs, provided a more realistic use of the language. Supporting this definition were the commentaries of Trisha and Marcio:

[43] Trisha: "It is important because dialogues are closer to spontaneous speech (even if they are decorated texts) relatively to vocabulary, speed, etc". (Questionnaire) ${ }^{7}$

[27] Marcio: "In understanding the informal language used, making it less "strange" to talk to natives who usually use slang”. (Questionnaire) ${ }^{8}$

Another characteristic of authentic material observed by participants was the exposure to the culture of the spoken language, as observed in the statement of participant Leo:

[26] Leo: "It's a nice way to learn the language and to absorb the culture or behavior within other characteristics of that country as well". (Questionnaire) ${ }^{9}$

\footnotetext{
${ }^{2}$ My translation from the original: É a forma mais fácil de entrar em contanto com a língua durante o meu dia.

${ }^{3}$ My translation from the original: Auxilia pela exposição ao idioma, algo que raramente é possível na minha rotina.

${ }^{4}$ My translation from the original: Me trás mais familiaridade com as palavras.

${ }^{5}$ My translation from the original: A fala dos nativos ajuda no aumento de vocabulário e de como algumas expressões devem ser empregadas numa frase

${ }^{6}$ My translation from the original: Observando o vocabulário utilizado em diversos contextos do dia-a-dia dos personagens.

${ }^{7}$ My translation from the original: É importante pelo fato de os diálogos estarem mais próximos da fala espontânea (mesmo que sejam textos decorados) em relação ao vocabulário, a velocidade, etc.

${ }^{8}$ My translation from the original: No entendimento da linguagem informal utilizada, sendo menos "estranho" conversar com nativos que costuma usar gírias.

${ }^{9}$ My translation from the original: É uma forma agradável de aprender o idioma e absorver também a cultura, o comportamento dentro outras características daquele país.
} 
The third observed theme was 3) pronunciation; several participants stated that TV series could contribute to the learning of pronunciation, as highlighted by participants Ana and Rafael:

[1] Ana: "Watching series in English helps to learn the pronunciation of the words", (Questionnaire) ${ }^{10}$

[30] Rafael: “Improving the pronunciation of the word”. (Questionnaire) $)^{11}$

Other participants observed the correct intonation of the characters, as presented in the statement of participant Nelma, as well as, the good dictation of the characters, as mentioned in the statement of participant Italo:

[6] Nelma: Helps me to understand the situations of use of the English language, use the correct intonation. (Questionnaire) $^{12}$

[37] Italo: “A good diction of the speaker". (Questionnaire) ${ }^{13}$

These important features of the TV series contribute significantly to the improvement of the listening skills, as Brown (2001) pointed out in his work several factors that make listening difficult, among these factors, were the use of reduced forms, the use of colloquial language, the rate of delivery, and the stress, rhythm, and intonation of the English language.

Moreover, to infer meaning not only the visual aids are important but also the speech itself and how it is being delivered. The language choices of a character, their expressions and words as well as their intonation, can inform a listener of his origin, social status, even his age as well as if the character is being funny or sarcastic. These features of the language present in the TV series can help students' interpretation and to gain familiarity with different forms of speech. Thus, conducting to the fourth theme observed, 4) listening practice and comprehension.

Regarding the before-mentioned theme, some participants stated that TV series could improve listening comprehension, especially because offered authentic situations of listening, such as perceived in the statement of Ingrid:

[20] Ingrid: "Expanding the commonly spoken English, different from the more leisurely and formal audios used in the classroom". (Questionnaire) $)^{14}$

Also because it functions as training for realistic listening, this was pointed out by a few participants and can be demonstrated in the statements of Weber:

[44] Weber: "It works as a type of training, helping to familiarize you with both listening and speaking", (Questionnaire) $^{15}$

According to Goh (1999), students are constantly requested to speak in class, especially when collaborating with others, but listening actively with a purpose in mind is often neglected by teachers.

\footnotetext{
${ }^{10}$ My translation from the original: Assistir as séries em inglês auxilia no aprendizado da pronúncia das palavras.

11 My translation from the original: A melhorar a pronuncia da palavra.

${ }^{12}$ My translation from the original: Auxilia-me a entender situações de uso da lingual inglesa, a utilizar a entonação correta.

${ }^{13}$ My translation from the original: Uma boa dicção do falante.

${ }^{14}$ My translation from the original: Expandindo o inglês usualmente falado, diferentes dos áudios mais pausados e formais da sala.

15 My translation from the original: Funciona como um tipo de treinamento, ajudando na familiarização com o idioma, tanto para escutar quanto para falar.
} 
On this particular aspect, language teaching has been heavily associated with discerning sound, and providing teachers with specific information when requested (Goh, 1999), such practice may cause anxiety in students, especially beginners, that have difficulties in listening comprehension as well as language production.

When watching TV series, students are focused on inferencing meaning, and making interpretations, they do not need to reply to the characters, and for that reason can concentrate on what is being said rather than how to respond to their statements. This assistance with interpretation was observed by students Aila and Hanna:

[13] Aila: "[...]. Besides, the practicing of watching English-subtitled series helps with fluidity, making it easier to understand other audios later". (Questionnaire) ${ }^{16}$

[36] Hanna: “[...] Speed to interpret the audios". (Questionnaire) $)^{17}$

The last theme observed was 5) motivation; since TV series are watched mostly for entertainment, the attachment to the characters, their stories, and even the actors portraying these characters, can motivate students in trying to understand what is being represented in their screens, as demonstrated by Aline:

[14] Aline: "I believe that watching something I like being by the plot of the series or the actors themselves motivates me to try to understand what they are dealing with in the series". (Questionnaire) ${ }^{18}$

Furthermore, through the analyses of the content of the answers, it was possible to identify learning strategies being reported by participants. One example of strategy identified was the cognitive strategy Inferencing, reported by Lucas, and Isis:

[24] Lucas: "I try to watch in the original language (English) with English subtitles as well, so I try to understand the words I don't know by the context [...]”. (Questionnaire) ${ }^{19}$

[21] Isis: "Especially with listening, sometimes I try to ignore the subtitles and try to understand what is being said $[\ldots]$ '. (Questionnaire) $)^{20}$

Another example of cognitive strategy found was repetition, demonstrated in the statement of participant Tami:

[11] Tami: "I try to pronounce the words with the same intonation as the character [...]". (Questionnaire) ${ }^{21}$

Moreover, the cognitive strategy contextualization was identified in the statement of participant Felipe:

[35] Felipe: "I watch series that I identify myself with and now and then I use the pronunciations I learn in my daily life". (Questionnaire) $)^{22}$

\footnotetext{
${ }^{16}$ My translation from the original: [...]. Além de que a praticar de ver séries com legenda em inglês ajudam na fluidez se torna mais fácil de compreender outros áudios depois.

${ }^{17}$ My translation from the original: [...]. Rapidez para interpretar os áudios.

${ }^{18}$ My translation from the original: Acredito que ao assistir algo de que gosto seja pelo enredo da série ou dos próprios atores me motiva a tentar compreender o que estão tratando na série.

${ }^{19}$ My translation from the original: Tento assistir na linguagem original (inglês) e a legenda também em inglês, assim tento com preender as palavras que não conheço pelo contexto [...].

${ }^{20}$ My translation from the original: Principalmente com listening, as vezes tento ignorar a legenda e tentar entender o que está sendo dito [...].

${ }^{21}$ My translation from the original: Eu tento pronunciar as palavras com a mesma entonação que o personagem [...].

${ }^{22}$ My translation from the original: Assisto séries as quais me identifico e volta e meia passo a utilizar as pronuncias que aprendo em meu cotidiano.
} 
For Nascimento and Feitosa (2020, p. 12), "the learning experienced by the student, becomes more meaningful and effective when he himself seeks to learn" ${ }^{23}$, as observed in the statements above. Furthermore, Watkins (2005) discussed several factors that he perceived as essential for language learning. Part of these elements was recognized by participants, as contributions to their learning process. An example was the acquisition of vocabulary, especially while observing the language used in context. Furthermore, he stated that "there are a huge number of words in the language, and it is impossible for a teacher to teach more than a fairly small portion of them. Some time can, therefore, be usefully used in helping learners to learn effectively outside the classroom" (Watkins, 2005, p.34).

Moreover, another determinant approached by the scholar was the cultural awareness, students must perceive the context so to respond appropriately. For Zimmer and Azevedo (2020, p. 1), "Contextualizing a student culturally means leading them to think about the foreign language with criticality and awareness of the differences between it [Foreign Language] and their native language ${ }^{24 "}$.

Additionally, the last factor observed was pronunciation, students need to be able to identify patterns of the speech. Therefore, "teaching learners to recognize and understand the pronunciation of others will help enormously, with their ability to listen effectively, and the models later feed into their own production of Language" (Watkins, 2005, p.49).

\subsubsection{Have you ever heard about learning strategies? Where?}

In this study, it was observed that 30 participants $(68.2 \%)$ knew or had heard at least once about learning strategies. Moreover, 14 participants (31.8\%) learned about such strategies through their English teacher at CLLE and 4 participants (9.09\%) learned with their graduations. Furthermore, 2 participants (4.54\%) learned with the internet, 5 (11.36\%) learned from Youtube videos, and 1 (2.27\%) from online courses and handouts. Even Social Medias, as Instagram was reported by 2 participants (4.54\%). Additionally, 1 participant (2.27\%) learned from other friends and 1 (2.27\%) in the workplace. But even the ones that initially learned with their teacher at CLLE also use the Internet to some degree to learn more about the learning strategies.

It was also observed that, 14 participants (31.8\%) have never heard of listening strategies. Even though, relying on several different set of listening comprehension strategies while watching TV series, demonstrating the unconsciousness use of the learning strategies. As Boonkit (2002, p.79) observed "language learners often unconsciously use one, or another type of learning strategy to assist any language task, either in the classroom or in the real world".

\subsection{Questionnaire closed-ended items results}

\subsubsection{Background information results}

Table 5 presents participants' self-evaluation on their listening, and speaking performance, both inside, and outside the classroom context, as well as their listening attitudes towards the TV series, as for the frequency of watching the series, the use of subtitles, and the use of other means to practice such abilities.

\footnotetext{
${ }^{23}$ My translation from the original: "A aprendizagem vivenciada pelo aluno, se torna mais significativa e eficaz quando ele mesmo buscar aprender". (Nascimento \& Feitosa, 2020, p. 12)

${ }^{24}$ My translation from the original: "Contextualizar culturamente um aluno é leva-lo a pensar a língua estrangeira com criticidade e consciência das diferenças entre esta [Língua Estrangeira] e sua língua nativa”. (Zimmer \& Azevedo, 2020, p. 1)
} 
Table 5 - Background Information.

\begin{tabular}{|c|c|c|c|c|c|}
\hline Item & $\begin{array}{l}\text { Never } \\
\text { (1) }\end{array}$ & $\begin{array}{l}\text { Rarely } \\
(2)\end{array}$ & $\begin{array}{c}\text { Sometimes } \\
(3)\end{array}$ & $\begin{array}{l}\text { Almost } \\
\text { Always (4) }\end{array}$ & $\begin{array}{c}\text { Always } \\
(5)\end{array}$ \\
\hline \multicolumn{6}{|l|}{ Self Awareness } \\
\hline 1. I consider my ability of listening & 0 & 4 & 23 & 14 & 3 \\
\hline satisfactory & $0,00 \%$ & $9,09 \%$ & $52,27 \%$ & $31,82 \%$ & $6,82 \%$ \\
\hline 2. I can easily understand the audios in the & 1 & 4 & 14 & 17 & 8 \\
\hline classroom. & $2,27 \%$ & $9,09 \%$ & $31,82 \%$ & $38,64 \%$ & $18,18 \%$ \\
\hline 3. I get nervous and anxious when listening & 10 & 11 & 14 & 8 & 1 \\
\hline to audios in the classroom. & $22,73 \%$ & $25,00 \%$ & $31,82 \%$ & $18,18 \%$ & $2,27 \%$ \\
\hline \multirow[t]{2}{*}{ 4. I try to speak as a native speaker. } & 10 & 9 & 6 & 10 & 9 \\
\hline & $22,73 \%$ & $20,45 \%$ & $13,64 \%$ & $22,73 \%$ & $20,45 \%$ \\
\hline 8. I feel comfortable when speaking in English & 6 & 16 & 12 & 6 & 4 \\
\hline with other people. & $13,64 \%$ & $36,36 \%$ & $27,27 \%$ & $13,64 \%$ & $9,09 \%$ \\
\hline \multicolumn{6}{|l|}{ Outside Listening Behavior } \\
\hline 5. I often watch television series in & 1 & 3 & 10 & 10 & 20 \\
\hline English. & $2,27 \%$ & $6,82 \%$ & $22,73 \%$ & $22,73 \%$ & $45,45 \%$ \\
\hline 6. I watch TV series in English with & 1 & 3 & 8 & 15 & 17 \\
\hline Portuguese subtitles & $2,27 \%$ & $6,82 \%$ & $18,18 \%$ & $34,09 \%$ & $38,64 \%$ \\
\hline 7. I use other means to practice my & 0 & 5 & 12 & 11 & 16 \\
\hline listening ability, for example listening to & $0,00 \%$ & $11,36 \%$ & $27,27 \%$ & $25,00 \%$ & $36,36 \%$ \\
\hline English music, chat with foreigners, etc. & & & & & \\
\hline
\end{tabular}

Source: Prepared by the author of the work.

In the self-awareness category, regarding participants' perception of their listening abilities, 17 participants considered their overall listening ability as always or almost always satisfying. In contrast, 4 participants evaluated their overall listening ability as rarely or never satisfactory. As for the specific classroom context of listening, more than half of the participants (25) perceived that their listening comprehension in the classroom was always or almost always simplistic and undemanding, where only 5 participants demonstrated having some difficulties with their listening in the classroom context. Such findings coincided with the results of item three, where 21 participants reported not feeling nervous or anxious while listening to classroom audios, versus 9 participants that expressed always or almost always feeling anxiety and nervousness while listening to the classroom audios.

Concerning participants' perception of their speaking skills, the results revealed that half of the participants (22) rarely or never feel comfortable when speaking in English with others. In opposition, 10 participants demonstrated always or almost always feeling relaxation and comfort. Furthermore, 19 participants revealed that they always or almost always aspire to speak like native speakers, against the same number of participants that expressed rarely or never attempting to speak like native speakers, and solely 6 participants reported an occasional occurrence.

Regarding participants' outside the classroom listening behavior, the results revealed that the majority of participants (30) always or almost always watch television series, whereas 10 participants solely watch sometimes and 4 participants rarely or never watch. Although most participants reported a high frequency of watching TV series, the majority of participants (32) reported always or almost always using subtitles, 8 participants reported sometimes using subtitles, and 4 participants reported rarely or never using subtitles. Additionally, 27 participants reported resorting to other means to practice their listening, 12 reported sometimes resorting, and 5 participants reported rarely or never appealing to other tactics as a way of practice. 


\subsubsection{Cognitive strategies results}

Table 6 presents the absolute frequency and the relative frequency of use, of each cognitive strategy described in the Likert scale items. The cognitive strategies are related to how participants manipulate the information present in the TV series, as to achieve listening comprehension.

Table 6 - Cognitive Strategies.

\begin{tabular}{|c|c|c|c|c|c|}
\hline Strategy/ Item & $\begin{array}{l}\text { Never } \\
(1)\end{array}$ & $\begin{array}{l}\text { Rarely } \\
(2)\end{array}$ & $\begin{array}{c}\text { Sometimes } \\
\text { (3) }\end{array}$ & $\begin{array}{l}\text { Almost } \\
\text { Always (4) }\end{array}$ & $\begin{array}{l}\text { Always } \\
(5)\end{array}$ \\
\hline \multicolumn{6}{|l|}{ Listening for details } \\
\hline 10. I try to understand word by word of what is & 1 & 5 & 17 & 15 & 6 \\
\hline being said. & $2,27 \%$ & $11,36 \%$ & $38,64 \%$ & $34,09 \%$ & $13,64 \%$ \\
\hline \multicolumn{6}{|l|}{ Inferencing } \\
\hline 9. I try to guess what will be said in the & 15 & 6 & 12 & 8 & 3 \\
\hline following scene. & $34,09 \%$ & $13,64 \%$ & $27,27 \%$ & $18,18 \%$ & $6,82 \%$ \\
\hline 11. I try to understand the words that I don't know from & 0 & 2 & 13 & 12 & 17 \\
\hline the context. & $0,00 \%$ & $4,55 \%$ & $29,55 \%$ & $27,27 \%$ & $38,64 \%$ \\
\hline \multicolumn{6}{|l|}{ Direct physical response } \\
\hline 12. I use the body language of characters to infer & 2 & 5 & 10 & 19 & 8 \\
\hline meaning of the words that I don't know. & $4,55 \%$ & $11,36 \%$ & $22,73 \%$ & $43,18 \%$ & $18,18 \%$ \\
\hline \multicolumn{6}{|l|}{ Elaboration } \\
\hline 13. I use my experiences and knowledge to understand & 0 & 1 & 6 & 18 & 19 \\
\hline the audios. & $0,00 \%$ & $2,27 \%$ & $13,64 \%$ & $40,91 \%$ & $43,18 \%$ \\
\hline \multicolumn{6}{|l|}{ Repetition } \\
\hline 14. As I listen to the words, I try to reproduce their & 2 & 4 & 8 & 15 & 15 \\
\hline pronunciation. & $4,55 \%$ & $9,09 \%$ & $18,18 \%$ & $34,09 \%$ & $34,09 \%$ \\
\hline \multicolumn{6}{|l|}{ Resourcing } \\
\hline 15. I write down the words that I don't know and look & 9 & 10 & 7 & 8 & 10 \\
\hline them up in the dictionary. & $20,45 \%$ & $22,73 \%$ & $15,91 \%$ & $18,18 \%$ & $22,73 \%$ \\
\hline \multicolumn{6}{|l|}{ Imagery } \\
\hline 16. To remember the meaning of a word, I try to & 4 & 3 & 16 & 10 & 11 \\
\hline $\begin{array}{l}\text { remember the situation in which this word was used in a } \\
\text { series. }\end{array}$ & $9,09 \%$ & $6,82 \%$ & $36,36 \%$ & $22,73 \%$ & $25,00 \%$ \\
\hline \multicolumn{6}{|l|}{ Contextualization } \\
\hline 17. I try to employ in the classroom the words that I & 4 & 10 & 15 & 6 & 9 \\
\hline learned with television series & $9,09 \%$ & $22,73 \%$ & $34,09 \%$ & $13,64 \%$ & $20,45 \%$ \\
\hline \multicolumn{6}{|l|}{ Translation } \\
\hline 18. I first translated information into Portuguese and then & 4 & 9 & 15 & 14 & 2 \\
\hline think about its meaning. & $9,09 \%$ & $20,45 \%$ & $34,09 \%$ & $31,82 \%$ & $4,55 \%$ \\
\hline
\end{tabular}

Source: Prepared by the author of the work.

As demonstrated in Table 6, elaboration was the most used cognitive strategy, 37 participants demonstrated almost always or always using their experiences and background knowledge to understand the dialogues present in the TV series. In contrast, 1 participant reported rarely using such a strategy. Moreover, repetition was the second most used cognitive strategy, 30 participants expressed almost always or always repeating the words as they listen, against 6 participants that never or rarely repeat the words. The use of repetition was demonstrated in the statement of participant Tami [page 10].

As for the cognitive strategy Inferencing, the results were ambivalent. Most participants (29) demonstrated using the context to infer the meaning of unfamiliar words and expressions (item 11). Although as for the prediction of future speeches and scenes (item 9), most participants (21) reported a low frequency of use of the same strategy. Supporting such finding was the cognitive strategy direct physical response results, which revealed that 27 participants always or almost always use the 
characters' body language to infer the meaning of unknown words and expressions. In contrast, 7 participants never or rarely use this strategy.

Such strategies can prove to be integral for any listening comprehension, as appointed out by Rost (1990, p. 33) that stated that "understanding spoken language is essentially an inferential process based on a perception of cues rather than a straightforward matching of sound to meaning".

Under the description above are the statements of students Lucas and Isis respectively [page 10], and their use of Inferencing reported in the questionnaire.

Regarding the cognitive strategy contextualization, the results for high and medium frequency of use were identical, 15 participants reported employing in the classroom, what they have learned with the TV series, against 14 participants that reported never or rarely using this strategy.

For Watkins (2005) the new language acquired needs to be contextualized, as Zimmer and Azevedo (2020, p. 4) pointed out that "the teaching of English or any other foreign language can be enhanced [...], when the student inserts in his own history/life, the experiences proposed by his interpretation". ${ }^{25}$

Moreover Little, Dam and Legenhausen (2017) stated that linguistic communication fluency depends on a complex set of skills which students can assist its development, by learning words about topics of interest, practicing their pronunciation, as well as the phrases where they are likely to be used, increasing the chances of being understood by their peers. Therefore, the low frequency of use of the strategy contextualization was a surprise.

Nevertheless, such findings could be associated with a combination of causes, such as; reduced speaking moments in class, the context inadequacy for the words learned from the TV series, or solely, a lack of interest in practicing the words learned. However, the benefit of such a strategy was observed by participant Felipe [page 10], who demonstrated the use of the strategy contextualization to assist his oral production.

Concerning the strategy listening for details, 21 participants pointed out that they always or almost always attempt to understand word by word of the dialogues as they listen, against 6 participants that never or rarely attempt. Likewise, 21 participants demonstrated a moderate frequency of use of the cognitive strategy imagery, which is when students resort to memories of past scenes to remember the meaning of a word or expression, versus 7 participants that never or rarely use this strategy.

$\mathrm{Wu}$ (2008) demonstrated that students with distinct levels of proficiency employ different strategies. So the result for the listening for details strategy can be related to students' proficiency, since they were taking the last semester of their course and for that reason, had already an extensive contact with the language and familiarity with grammar structures, vocabulary, and overall knowledge of where and how words and expressions should be used, providing the opportunity to deduce meaning by the context, rather than by examining word by word. Such an assumption was followed Magalhães (1997) when she observed that, beginners tend to rely more on recognizing words, as a consequence of their limited vocabulary and limited knowledge of how the studied language operates.

As for the cognitive strategy translation, 16 participants reported always or almost always translating the information to Portuguese and subsequently reflecting on its meaning. In contrast, 13 participants demonstrated never or rarely translated the information.

Lastly, the strategy resourcing was the least used. Most participants (19) revealed rarely or never using such a strategy. In contrast, 18 participants demonstrated always or almost always resorting to dictionaries to search for unfamiliar words.

${ }^{25}$ My translation from the original: "O ensino de inglês ou de qualquer outra língua estrangeira pode ser potencializado [...], momento em que o estudante insere em sua própria história/vida, as experiências propostas pela leitura”. (Zimmer \& Azevedo, 2020, p. 4) 
The low-frequency results for the latter strategies could likewise relate to students language proficiency, since the necessity for this two strategies holds a secondary role in proficient students oral comprehension, as they already possess an extended vocabulary, and further practice into thinking in the target language, resorting to translation solely in specific situations. The previously mentioned practice is applied by CLLE teachers, since the initial levels of the course, as even novices are encouraged to think in the target language, thereby fluency could develop more naturally.

\subsubsection{Metacognitive strategies results}

Table 7 presents the absolute frequency and the relative frequency of use, of each metacognitive strategy described in the Likert scale items. The Metacognitive strategies are related to how students evaluate and monitor their listening ability while watching TV series, as well as how they manage their listening comprehension for positive outcomes.

Table 7 - Metacognitive Strategies.

\begin{tabular}{|c|c|c|c|c|c|}
\hline Strategy/Item & $\begin{array}{c}\text { Never } \\
(1)\end{array}$ & $\begin{array}{c}\text { Rarely } \\
(2)\end{array}$ & $\begin{array}{l}\text { Sometimes } \\
\text { (3) }\end{array}$ & $\begin{array}{l}\text { Almost } \\
\text { Always (4) }\end{array}$ & $\begin{array}{c}\text { Always } \\
(5)\end{array}$ \\
\hline \multicolumn{6}{|l|}{ Self-monitoring } \\
\hline 19. When I watch TV series with English & 3 & 9 & 23 & 7 & 2 \\
\hline $\begin{array}{l}\text { subtitles I often find myself ignoring the } \\
\text { subtitles. }\end{array}$ & $6,82 \%$ & $20,45 \%$ & $52,27 \%$ & $15,91 \%$ & $4,55 \%$ \\
\hline \multirow{2}{*}{$\begin{array}{l}25 . \text { I notice mistakes I made when using the language } \\
\text { when I observe a character using the word correctly. }\end{array}$} & 1 & 5 & 9 & 15 & 14 \\
\hline & $2,27 \%$ & $11,36 \%$ & $20,45 \%$ & $34,09 \%$ & $31,82 \%$ \\
\hline \multicolumn{6}{|l|}{ Self-evaluation } \\
\hline \multirow{2}{*}{$\begin{array}{l}\text { 20. I can easily understand the audio present in television } \\
\text { series. }\end{array}$} & 0 & 9 & 19 & 16 & 0 \\
\hline & $0,00 \%$ & $20,45 \%$ & $43,18 \%$ & $36,36 \%$ & $0,00 \%$ \\
\hline \multirow[t]{2}{*}{ 24. I wonder if I am satisfied with my understanding. } & 4 & 0 & 11 & 8 & 21 \\
\hline & $9,09 \%$ & $0,00 \%$ & $25,00 \%$ & $18,18 \%$ & $47,73 \%$ \\
\hline \multirow{2}{*}{$\begin{array}{l}\text { 26. I think about what new expressions, words, or } \\
\text { pronunciations I learned from series }\end{array}$} & 1 & 6 & 11 & 13 & 13 \\
\hline & $2,27 \%$ & $13,64 \%$ & $25,00 \%$ & $29,55 \%$ & $29,55 \%$ \\
\hline \multicolumn{6}{|l|}{ Self- management } \\
\hline \multirow{2}{*}{$\begin{array}{l}\text { 21. When the dialogue has vocabulary that I don't know I } \\
\text { give up on watching. }\end{array}$} & 22 & 15 & 5 & 1 & 1 \\
\hline & $50,00 \%$ & $34,09 \%$ & $11,36 \%$ & $2,27 \%$ & $2,27 \%$ \\
\hline \multirow{2}{*}{$\begin{array}{l}\text { 22. I get familiar with the colloquial language, jargon and } \\
\text { slang present in television series. }\end{array}$} & 3 & 8 & 16 & 11 & 6 \\
\hline & $6,82 \%$ & $18,18 \%$ & $36,36 \%$ & $25,00 \%$ & $13,64 \%$ \\
\hline \multicolumn{6}{|l|}{ Direct- attention } \\
\hline \multirow[t]{2}{*}{ 23. I focus more on topic dialogues than I am unaware of. } & 6 & 11 & 18 & 7 & 2 \\
\hline & $13,64 \%$ & $25,00 \%$ & $40,91 \%$ & $15,91 \%$ & $4,55 \%$ \\
\hline
\end{tabular}

Source: Prepared by the author of the work.

As demonstrated in Table 7, the results for the metacognitive strategy self-monitoring revealed that 9 participants always or almost always perceive themselves ignoring the subtitles (item 19), whereas 23 participants sometimes perceive, and 12 participants never or rarely notice themselves ignoring the subtitles. Moreover, the majority of participants (29), always or almost always correct their language mistakes, while observing words and expressions being accurately used by a character (item 25), against 9 that sometimes correct and 6 that never or rarely realize their own mistakes. Controlling one's abilities and efforts in learning have been observed by Vandergrift (1999, p. 174) as "crucial to success in listening comprehension".

The results for the metacognitive strategy self-evaluation revealed that none participant reported that never comprehend or that always comprehend the audios present in the TV series (item 20). Although 16 participants reported almost always understanding, against 9 participants that reported rarely understanding the audios present in TV series. Though fewer participants reported having difficulties with understanding, the majority of participants (29) reported evaluating their listening 
comprehension while watching TV series (item 24), against 4 participants that never evaluate. Furthermore, most participants (26) reported reflecting on what is being learned with the TV series (item 26), against 11 the sometimes reflect and 7 that never or rarely reflects on their learning. As Nunan (1991, p.172) stated that student's efficacy resides greatly in their abilities to "reflect on and articulate their language learning process", by developing autonomy, the student is able to "build his knowledge instead of passively acquiring with the teacher"26 (Nascimento \& Feitosa, 2020, p. 5).

Regarding the self-management category, the results demonstrated that the majority of participants (37) persist on watching the TV series, even when confronted with listening difficulties (item 21), 5 participants sometimes cease watching the TV series, and 2 participants reported almost always or always giving up watching the series when facing listening difficulties.

Osada (2004) observed that students may give up on listening, because requires great quantity of effort in understanding meaning; however when the topic of the listening is of interest of the student, concentration can be easier. Such was demonstrated in the statement of participant Aline [page 9]

Furthermore, 17 participants reported familiarizing with colloquial languages present on the TV series (item 22), against 16 that sometimes familiarize, and 11 that never or rarely familiarize with the informal language present in the series. Intentionally familiarizing with the words, expressions and how to produce sounds accurately, was observed through students' reported use of the metacognitive strategy self-management, as demonstrated in the statements of students Geovana and Roberto:

[19] Geovana: "I feel more familiar with the native language and its everyday applications". (Questionnaire) ${ }^{27}$

[29] Roberto: "Helps me to understand native phrases and expressions that are commonly used in everyday life".

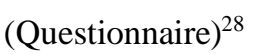

For the metacognitive strategy direct-attention (item 23), the results revealed that solely 9 participants almost always or always focus more on the listening when confronted with unfamiliar topics, 18 participants expressed sometimes paying extra attention and 17 participants never or rarely concentrate more when dealing with unknown themes.

For Nascimento and Feitosa (2020, p. 4), “[...] educating young people inserted in an increasingly versatile, digital world [...], conditioned the education systems to develop methodologies that proposed a more active and autonomous student, responsible for their learning"29. Additionally, Zimmer and Azevedo (2020, p. 13), proposed the use of new technologies' (video clips) for cultural immersion, since it is "[ ...] an action that students already experience in their daily lives $[\ldots]$ ". ${ }^{30}$.

Therefore, the results for the metacognitive strategies that proved to be highly adopted by students, demonstrated that TV series can be a helpful instrument for language learning. Since, when students constantly examine their listening comprehension, evaluate what has been learned with the TV series, and monitor their own language mistakes, they can transfer this ability from the particular context of the TV series, to their overall language learning process, and with that, gaining control of their learning.

\footnotetext{
${ }^{26}$ My translation from the original: "Construir seu conhecimento em vez de adquirir com o professor, de forma passiva". (Nascimento \& Feitosa, 2020, p. 5).

${ }^{27}$ My translation from the original: "Me sinto mais familiarizada com a linguagem nativa, e suas aplicações cotidianas".

${ }^{28}$ My translation from the original: "Me auxilia a compreender frases e expresses nativas que são comumente usadas no dia-a-dia".

${ }^{29}$ My translation from the original: "[...] educar jovens inseridos em um mundo cada vez mais versátil, digital [...], condicionaram os sistemas de ensino a desenvolverem metodologias que propusessem um aluno mais atuante e autônomo e responsável pela sua aprendizagem". (Nascimento \& Feitosa, 2020, p. 4)

${ }^{30}$ My translation from the original: “[...] uma ação que os estudantes já vivenciam em seu cotidiano, [...]”. (Zimmer \& Azevedo, 2020, p. 13)
} 


\section{Conclusion}

After interpreting the results, the exposure to TV series proved to be a valuable tool for language learning, as they provide students with authentic vocabulary, different forms of speech and culture, as well as motivation. Nonetheless, students should approach such TV programs with a purpose in mind, establishing goals, perceiving them as instruments for language learning practice, which requires actively engaging in understanding, and continuous use of learning strategies so to achieve positive outcomes of comprehension, and overcome potential difficulties. The finding also revealed that the use of learning strategies affects positively students' oral comprehension and performance, and that it is inherent to any attempt of listening comprehension since students employ such strategies either consciously or unconsciously.

Furthermore, this research shed light within ways teachers can improve learners oral abilities, by demonstrating simple strategies that learners can use to improve so skills, such as; systematically ignoring the subtitles, searching for clues within the context to infer meaning of unfamiliar expressions, repeating words and statements to practice pronunciation, as well as intonation, stress, and rhythm, of the English language, applying words and sentences learned from the TV series in their language classes, or while practicing English with friends, observing their language mistakes, familiarizing with typical colloquialisms of the English language, and mostly evaluating their learning process, reflecting on whichever has been learned from the TV series, as well as what needs more focus and effort. Employing these strategies in-class or out-of-class will improve students' oral language skills and any skill for that matter.

As for the limitations of the study, it is highlighted that the research sample size was not ideal for quantitative analysis, as well as the results obtained in this study, were derived from a non-probabilistic sample and are therefore not subject to generalizations.

Moreover, a secondary limitation that it is worth mentioning regards the methodology adopted in this research, the gathering of data made exclusively through questionnaire administration, could have been supported by an interview with students, as an interview would have provided additional information on students strategies use, as well as presenting specific data on the difficulties confronted by students while listening to authentic materials such as TV series, and the mechanisms students use as to deal with such challenges.

The third and final limitation is the absence of an instrument that could have properly evaluated students oral abilities, since such instrument would have had supported more efficiently the relationship between students strategy use, and the TV series contributions to students oral abilities, as well as demonstrating if students oral self-evaluation, in fact, represents their oral performance.

For future studies, it is suggested the design of lesson plans using selected TV series to teach learning strategies to students, as to investigate, if the strategies use and the exposure to the TV series could improve students' comprehension and speaking performance. Likewise, observing if students' equipped with those strategies can develop an autonomous behavior. Furthermore, it is highly recommended to investigate learning strategies being used with other materials as well, as to build a database of possibilities for effective language learning practices, both inside and outside the classroom environments.

\section{References}

Bardin, L. (2010). Análise de conteúdo [Content analysis] (L. A. Reto \& A. Pinheiro, Trans.): Edições 70. (Original work published 1977)

Boonkit, K. (2002). Listening Strategies with Television Texts: a study of Thai university students of English as a foreign Language. PhD thesis (Doctor in Philosophy) - University of Tasmania. Australia. https://eprints.utas.edu.au/19147/1/whole_BoonkitKamonpan2002_thesis.pdf

Brown, H. D. (2001). Teaching by Principles: An Interactive Approach to Language Pedagogy (2a ed.). White Plains, NY: Longman. https://octovany.files.wordpress.com/2013/12/ok-teaching-by-principles-h-douglas-brown.pdf

Dias, M., \& Navarro, R. (2018). Is Netflix Dominating Brazil? International Journal of Business and Management Review, 6(1), 19-32. https://doi.org/10.37745/ijbmr.2013 
Goh, C. M. (1999). Learning to Listen. National Institute of Education. Singapore. 44-53. https://repository.nie.edu.sg/bitstream/10497/3812/1/REACT-19992-44.pdf

Little, D., Dam, L., \& Legenhausen, L. (2017). Language learner autonomy: Theory, practice and research. Second Language acquisition: Multilingual Matters.

Magalhães, S. G. (1997). Estratégia de compreensão oral usadas por alunos de Inglês como língua estrangeira: Descrição e Classificação. Dissertação de Mestrado - Universidade Federal de Minas Gerais, Belo Horizonte. https://repositorio.ufmg.br/bitstream/1843/BUBD9E5G8P/1/dissertacao_gladysdesousamagalhaes.pdf

Morrow, K. (1977). Authentic texts and ESP. In S. Holden (Ed.), English for Specific Purposes (pp. 13-17): Modern English Publications.

Nascimento, J. L., \& Feitosa, R. A. (2020). Active methodologies, focusing on teaching and learning processes. Research, Society and Development, 9(9), e622997551. 10.33448/rsd-v9i9.7551.

Newman, I., \& Benz, C. R. (1998). Qualitative-quantitative research methodology: Exploring the interactive continuum. Carbondale: Southern Illinois University Press. https://pdfs.semanticscholar.org/9a57/63b63ed64c799ba5b9b060710b0b700e34c9.pdf

Nunan, D. (1991). Language teaching methodology: A textbook for teachers. Hemel Hempstead: Prentice Hall. https://epdf.pub/queue/language-teachingmethodology-a-textbook-for-teachers.html

Nunan, D. (2001). 6. New Ways In Teaching Listening. The Journal of TESOL FRANCE. Parler, Ecouter, Communiquer: Enhancing Speaking and Listening Skills. Marie-Pierre Beaulieu, 8, 51-66. https://www.tesol-france.org/en/pages/108/the-journal-volume-8-2001.html

O’Malley, J. M., et. al. (1985). Learning strategies used by beginning and intermediate ESL students. Language Learning, 35(1), 21-46. https://doi.org/10.1111/j.1467-1770.1985.tb01013.x

Osada, N. (2004). Listening comprehension research: A brief review of the past thirty years. Dialogue, 3, 53-66. https://www.researchgate.net/publication/267553667_Listening_Comprehension_Research_A_Brief_Review_of_the_Past_Thirty_Years

Oxford, R. L. (1990). Language learning strategies: What every teacher should know. New York: Newbury House. https://epdf.pub/queue/language-learningstrategies-what-every-teacher-should-know.html

Rost, M. (1990). Listening In Language Learning. London: Longman. https://doi.org/10.4324/9781315846699

Rubin, J. (1975). What the "good language learner" can teach us. TESOL Quarterly, 9(1), 41-51. https://doi.org/10.2307/3586011.

Stebbins, R. A. (2001). Exploratory research in the social sciences. Qualitative research methods, 48. Thousand Oaks: Sage Publications. https://www.researchgate.net/publication/309967516_Exploratory_research_in_the_social_sciences_what_is_exploration

Vandergrift, L., Goh, C., Mareschal, C., \& Tafaghodatari, M. H. (2006). The Metacognitive Awareness Listening Questionnaire (MALQ): Development and validation. Language Learning, 56(3), 431-462. https://www.academia.edu/3186922/The_metacognitive_awareness_listening_quest ionnaire_Development_and_validation

Vandergrift, L. (2004). Listening to learn or learning to listen? Annual Review of applied Linguistics, 24(1), 3-25. https://doi.org/10.1017/S0267190504000017

Vandergrift, L. (1999). Facilitating second language listening comprehension: acquiring successful strategies. ELT Journal, 53(3), 168-176, https://doi.org/10.1093/elt/53.3.168

Vandergrift, L. (1997). The comprehension strategies of second language (French) listeners: a descriptive study. Foreign Language Annals, 30(3), 387-409. https://doi.org/10.1111/j.1944-9720.1997.tb02362.x

Watkins, P. (2005). Leaning to teach English. Delta publisher. https://dlscrib.com/download/learning-to-teach-english watkins_58b6c4f064 54a7e879b1e8f7_pdf

Wu, Y. L. (2008). Language learning strategies used by students of different proficiency level. Asian EFL Journal, 10, 75-95. https://www.asian-efljournal.com/December_2008_EBook.pdf?q=2008-journal-of-proceedings\#page=75

Yin, M. (2015). The effect and importance of authentic language exposure in improving listening comprehension. Master's thesis (Master of Arts in English: Teaching English as a Second Language) Faculty of St. Cloud State University. USA. https://repository.stcloudstate. edu/cgi/viewcontent.cgi?article=1034\&context=engl_etds

Zimmer, R., \& Azevedo, L. F. (2020). Cultural immersion through the video clip under the perspective of applied linguistic to English teaching. Research, Society and Development, 9(9), e554997679.10.33448/rsd-v9i9.7679. 